\title{
More on the Pressing Global Problems, Socially and Ecologically
}

Deniz Atik

University of Texas Rio Grande Valley

Nikhilesh Dholakia

University of Rhode Island

Follow this and additional works at: https://digitalcommons.uri.edu/mgdr

Part of the Anthropology Commons, Economics Commons, Marketing Commons, Other Business Commons, and the Sociology Commons

\section{Recommended Citation}

Atik, Deniz and Dholakia, Nikhilesh (2019) "More on the Pressing Global Problems, Socially and Ecologically," Markets, Globalization \& Development Review: Vol. 4: No. 1, Article 1.

DOI: 10.23860/MGDR-2019-04-01-01

Available at: https://digitalcommons.uri.edu/mgdr/vol4/iss1/1

This Editorial is brought to you for free and open access by DigitalCommons@URI. It has been accepted for inclusion in Markets, Globalization \& Development Review by an authorized editor of DigitalCommons@URI. For more information, please contact digitalcommons-group@uri.edu. 
More on the Pressing Global Problems, Socially and Ecologically

\section{Markets, Globalization \& Development Review}
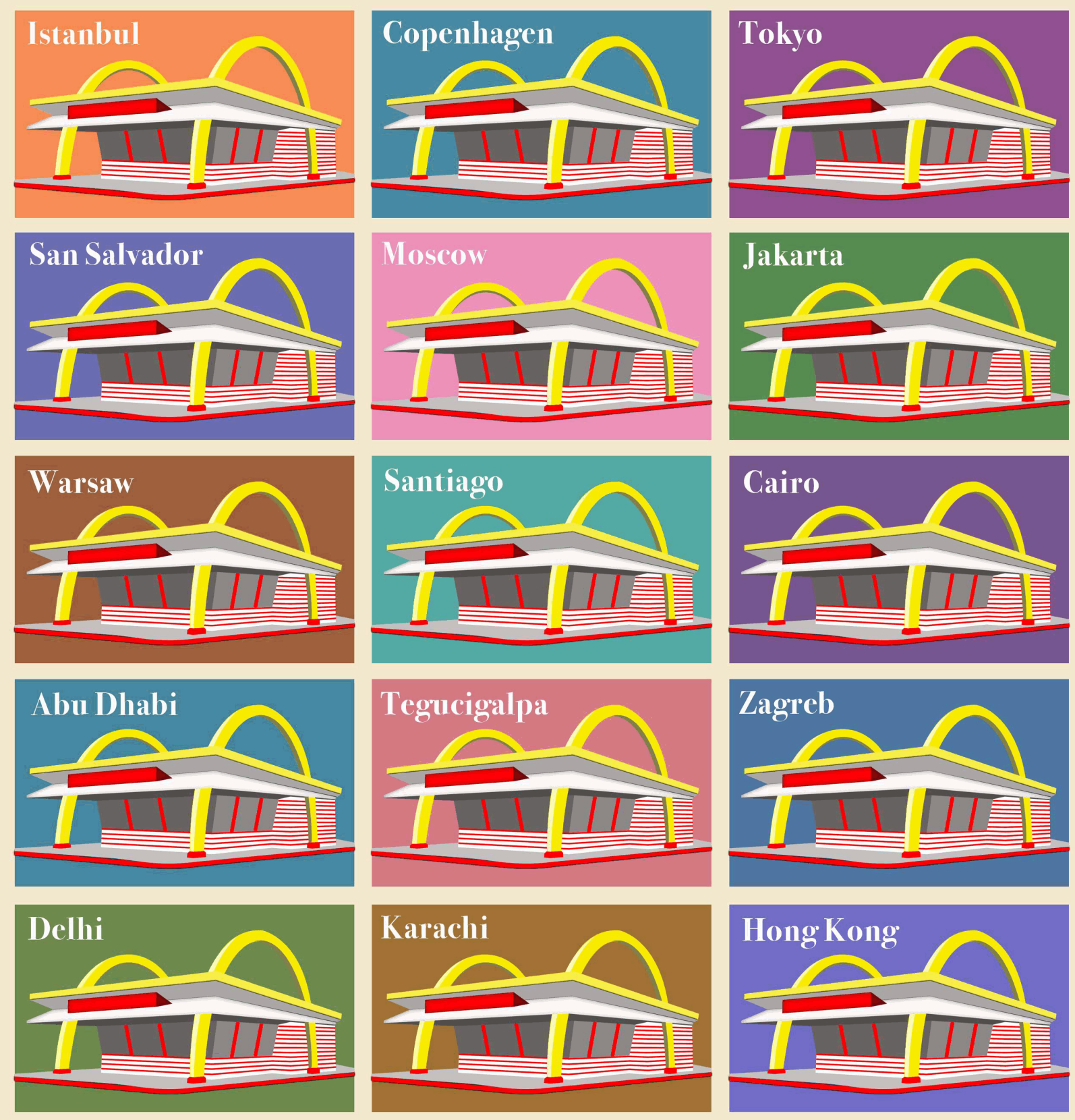

This editorial is available in Markets, Globalization \& Development Review: https://digitalcommons.uri.edu/mgdr/ vol4/iss $1 / 1$ 


\section{More on the Pressing Global Problems, Socially and Ecologically}

\section{Introduction}

In this first issue of Volume 4, as in the previous issues since the launch of Volume 1, Number 1 of MGDR in 2016, we continue to delve into the most pressing problems of the world. These include a range of difficult ecological and social problems. In ecological terms, this issue deals with the increasing shortages of water and its unfair distribution; and eco-social sustainability challenges in industries like fashion. MGDR of course engages with challenges associated with development initiatives in various parts of the world and Thailand is the focus in this issue. Neoliberal ideologies stretch even the religious boundaries and, in this issue, the halal wine and champagne market is explored. Also, in this issue, there is a focus on the Western discourse dominating the history of fashion and its beauty standards.

\section{Articles in this Issue}

In the first article of this first issue of Volume 4, Garcia-Ramon (2019) draws our attention to water scarcity and, with the dominance of globalizing agribusinesses, the unjust allocation of water in the world. She discusses how liberalization of land and natural resource markets, relaxing agricultural regulations in developing countries, and fastdeveloping bio-technologies resulted in transnational agribusiness giants to engage in massive land acquisitions (and pollution of those lands), forcing small farmers out of business in those countries. Through her conceptual analysis of the literature, she argues that agribusiness corporations have serious adverse impact on vulnerable consumers' access to clean water. Fertilizers used in growing the crops pollute water resources, making them unsafe to drink. Developed countries such as the U.S. have the resources to invest in water purification; but this is not as feasible and attainable in less developed parts of the world. Garcia-Ramon (2019) suggests that if solutions are to be found for the emerging water crises globally, they need to be implemented not only at the consumer level promoting frugality, but also - more importantly -- by regulating transnational agribusiness corporations that are responsible for $90 \%$ of water usage globally.

Fashion industry is one such major industry polluting water and soil through chemical and textile waste during both production and consumption processes. Accordingly, in the second article of this issue, Ozdamar-Ertekin (2019a) explores conceptually if luxury fashion can deliver solutions for a more sustainable fashion system. In her discussion, she first familiarizes the reader with the social and ecological problems associated with the fashion industry. She 
discusses the problems created especially by fast fashion retail giants dominating the industry. The core characteristics of fast fashion are speed, affordability, aesthetic fads, and therefore quick disposal; instead, luxury fashion is about longevity, authenticity, and quality as the author analyzes. Ozdamar-Ertekin (2019a) finds hope in luxury fashion by studying its core values in relation to sustainability principles such as durability, cultural heritage, and ecological and social consciousness. She also argues that luxury fashion companies would be less concerned with the higher cost of ethical and environmentally responsible fashion production because of the high prices they can charge. She also, however, presents the challenges associated with luxury fashion, since not everyone can afford it. Furthermore, she discusses the fashion sharing economy, as well as resale and rental channels, as potential ways to decrease textile waste and attain sustainability. Through her critical analysis concerning the social and environmental problems associated with fashion industry, we invite scholars to expand this discussion in the pages of MGDR with the hope to find further solutions to the wastefulness and carelessness of the industry.

The third article in this issue by Heingraj and Amornpan (2019) propose a potential solution to the kind of problems discussed in previous two articles, by introducing the Philosophy of Sufficiency Economy (PSE), which was initially developed to promote selfrealization in order to establish a sustainable living and economic development in Thai society. To cope with the challenges caused by globalization, PSE encourages a balanced way of life. It is based on three principles: moderation, reasonableness, and social immunity combined with knowledge and moral conditions - acknowledging an interconnectedness among people, society, and the environment. The authors examine the potential impacts of PSE especially at the individual level, as well as the challenges associated with its implementation. PSE takes the readers beyond the borders of capitalistic competition - which often neglects the social and environmental damages along the race to win - and emphasizes essential values for a more sustainable and balanced way of living.

Ironically, in the fourth article of this issue, we come back to the fierce neoliberal principles, stretching the boundaries of even the most rigid institutions such as religion. Kaptan (2019) reveals how Islamic actors such as halal certification institutions $(\mathrm{HCl})$ act with neoliberal ideologies in growing the halal market in Turkey. The author utilizes the field theory of Pierre Bourdieu to show how neoliberal policies of the Turkish government - promoting decentralization, privatization, and deregulation - have created new profit opportunities for the Islamic $\mathrm{HCls}$. Through a critical discourse analysis of the strategies of three leading HCls in Turkey, Kaptan (2019) presents the case of growing 
halal wine and champagne market to show how certain $\mathrm{HCls}$ stretch the Islamic boundaries. The author argues that "Turkish halal certification actors are simultaneously adapting, appropriating, and contesting Islamic discourses for justification of their existence and acquiring power in the formation and transformation of the emerging field of the Turkish halal market in the global neoliberal economy (p.2)." According to the author, these $\mathrm{HCls}$ also act as new cultural intermediaries disseminating Islamic education.

\section{Reviews in this Issue}

In addition to the articles, this first issue of 2019 also has one book review and one media review. Ozdamar-Ertekin (2019b) reviews the book by Linda Welters and Abby Lillethun, Fashion History: A Global View (2018) that provides a holistic perspective on fashion history not limited only to the West and to post-1350 Europe, but also including fashion in other parts of the world, covering a larger historical time span. The authors of the book also include everyday fashion (not only elite fashion) into their discourse and expand the historical meaning of fashion beyond the changing styles of dress to changing fabric patterns, hairstyles and colors, cosmetics, body decorations and modifications, and accessories. Ozdamar-Ertekin (2019b) meticulously analyzes different chapters of the book and crystalizes the book's main arguments such as the problems associated with Eurocentrism in fashion history, the misconception that fashion practice only occurred among the elite, the limiting of the scope of fashion only around dress, and the fallacy about the date of origin of fashion. In her final remarks, she makes a special emphasis on the pressing need for inclusivity in fashion not only from a historical perspective but also in practice, where diversity is a big challenge for the fashion industry.

Indeed, the next contribution in this issue is a media review about the urgent need for diversity in fashion and beauty industries. Cavusoglu (2019) starts her review of the film by Hayfa el Mansur, Nappily Ever After (2018), with a touching quote of the main character of the movie, a successful black career woman who struggles in chasing perfection with her hair under the pressures of dominant white beauty images. The movie is about her emotional struggles that are echoed in her hairstyle - ranging from straightened, weave, blonde, to bald - and eventually the character finally achieving serenity free from any burdens. Cavusoglu (2019) takes her review beyond the borders of the movie and delves into rich theoretical and historical insight about the globalization of Western beauty, dominance of whiteness in media, and the consequences of this underrepresentation. 


\section{Concluding Comment}

In summary, this issue of Volume 4 of MGDR focuses on agribusiness giant corporations overpowering small local farmers and restricting individual consumers' access to water resources; fast fashion retailers suppressing any potential sustainable alternatives; neoliberal ideologies surpassing even the religious boundaries; European discourse conquering world fashion history; and white supremacy ruling over other ethnicities and races in beauty industries. The invisible thread in this issue is about justice, fairness, inclusivity, and ecological awareness, which we, the editors of MGDR, perceive as the most pressing needs of the world today. Therefore, we would like to see many more such contributions in the pages of MGDR, offering ways to alleviate such problems, discussing potential alternative approaches and philosophies such as the Philosophy of Sufficiency Economy (PSE) in the case of Thailand, or luxury (and/or diversityenhancing) fashion business model potentially offering clues for sustainable solutions. 


\section{References}

Cavusoglu, Lena (2019), "Hayfa el Mansur, Nappily Ever After (2018): Chasing Perfection", Markets, Globalization \& Development $\begin{array}{lllll}\text { Review, } & 4 & \text { (1), } & \text { Article }\end{array}$ https://doi.org/10.23860/MGDR-2019-04-01-07

Garcia Ramon, Lorena (2019), "“Got Water?” The Effects of Globalized Agribusiness on Consumers' Access to Water Sources", Markets, Globalization \& Development Review, 4 (1), Article 2. https://doi.org/10.23860/MGDR-2019-04-01-02

Heingraj, Sasawan and Suwakitti Amornpan (2019), "The Introduction of Philosophy of Sufficiency Economy and Its Application to Consumer Context", Markets, Globalization \& Development Review, 4 (1), Article 4. https://doi.org/10.23860/MGDR-2019-04-01-04

Kaptan, Yesim (2019), "At the Nexus between the National and The Global: The Discursive Construction of the Turkish Halal Market in the Neoliberal Age," Markets, Globalization \& Development Review, $4 \quad(1), \quad$ Article 5. https://doi.org/10.23860/MGDR-2019-04-01-05

Ozdamar-Ertekin, Zeynep (2019a), "Fashion and Luxury," Markets, Globalization \& Development Review, 4 (1), Article 3. https://doi.org/10.23860/MGDR-2019-04-01-03

Ozdamar-Ertekin, Zeynep (2019b), "Book Review, Linda Welters and Abby Lillethun, Fashion History: A Global View (2018)," Markets, Globalization \& Development Review, 4 (1), Article 6. https://doi.org/10.23860/MGDR-2019-04-01-06 